\title{
An adaptive approach to water rights reform in South Australia
}

\author{
D. J. McKane \& I. Franssen \\ Department of Environment, Water and Natural Resources, \\ South Australia, Australia
}

\begin{abstract}
Water rights reform in Australia reached a milestone in 1994 with the Council of Australian Governments Water Reform Framework recognising that water property rights should be separated from land. The Agreement on a National Water Initiative (NWI) in 2004 progressed this reform further, separating the water right into an ongoing share of available water, an annual allocation volume and separate site specific approvals for taking and use, referred to as unbundling of water rights. The NWI envisaged unbundling water rights would assist water markets and assist flexible and efficient water resource management decisions.

South Australia commenced water reforms early, with water rights separated from land in 1983. In response to the NWI, South Australia passed legislation in 2007 to unbundle water rights. These reforms were implemented for the River Murray in 2009. The expansion of unbundling into other water resources will occur as part of the statutory review of the water allocation plans, which set the rules for allocating, trading, taking and using water. Whilst the unbundling of water rights has benefited River Murray water trade and assists adaptive management, the physical differences of the various water resources suggest different approaches to unbundling may be required. This paper discusses the South Australian policy on the implementation of unbundling of water rights, which provides an adaptive approach to water rights reform.

Keywords: unbundled water rights, South Australia, policy, River Murray.
\end{abstract}




\section{Introduction}

\subsection{Existing South Australian situation}

The Department of Environment, Water and Natural Resources (DEWNR) is responsible for water planning and management in South Australia. DEWNR also has the delegated authority to issue and vary water rights and authorisations, and to assess and approve or refuse transfers of water rights. These powers are vested in the Minister for Sustainability, Environment and Conservation (the Minister) by the South Australian Natural Resources Management Act (2004) [1].

Prescription of water rights occurs by regulation when it is considered necessary or desirable for the proper management of the resource. Figure 1 provides a map of all prescribed water resources in South Australia. Water rights are issued when water resources are prescribed. These water rights are separate from land and are tradeable to another person.

The National Water Commission (NWC) 2010-11 [2] water markets report records entitlement (permanent) water trades occurring in 13 prescribed water resource areas and that allocation (temporary) trades occurred in seven prescribed water resource areas in South Australia. The extent and depth of the water market varies greatly across prescribed water resources.

\subsection{National water initiative reforms}

The 1994 Council of Australian Government water reforms [3] and especially the 2004 NWI [4] contained commitments that States reform water rights. The 1994 reforms committed to a separation of the water rights from land. The NWI commitments require unbundling of water rights into separate components: an ongoing right to a share of available water, an annual allocation volume and separate site specific approvals for taking and use. All water rights along the River Murray (in New South Wales, Victoria and South Australia) are unbundled. Although the names of each component may vary across the States, they are similar enough to permit efficient and effective interstate trade arrangements [5].

In addition to unbundling water rights, the NWI reforms have reduced artificial barriers to trade, removed barriers within and introduced greater transparency in transfers out of areas managed by irrigation infrastructure operators, and have encouraged the formation of a National Water Market System which will contain a Common Registry System to allow quicker, simpler and more cost effective transfers.

\subsection{South Australian water rights reforms}

South Australia passed legislation to facilitate unbundling of water rights reform in 2007. These reforms were implemented for the River Murray in 2009 [1].The expansion of unbundling into other prescribed water resources will occur as part of the statutory water planning process. 
The unbundled water rights in South Australia are [6]:

Water access entitlement: this is the ongoing right to a specified share of the water available in a consumptive pool for the prescribed water resource and is issued on a water licence;

Water allocation: the right to take a specific volume of water for a given period of time, not exceeding 12 months, based on the volume of water available for allocation in that period;

Delivery capacity entitlement: the ongoing right to access a proportion of the capacity of a water distribution system;

Water resource works approval: the permission to construct, operate and maintain works for the purpose of taking prescribed water at a particular location, in a particular manner; and

Site use approval: the permission to use the water at a particular site in a particular manner.

\subsection{Water resource management in South Australia}

The State's Natural Resource Management (NRM) Boards are responsible for the development of water allocation plans for all prescribed water resources. DEWNR has responsibility for the administration of authorisations, issuing water access entitlements and allocations (licensing), approving trade of water rights and issuing water resource works and site use approvals and compliance activities. DEWNR and NRM Boards work closely together to ensure appropriate management of water resources.

Once a water resource is prescribed, anyone who takes water from that resource will need a water allocation. Exemptions apply in some cases for stock and/or domestic use and for incidental use such as fire fighting, where other forms of authorisations are granted. A water allocation plan is developed for each prescribed water resource, setting sustainable extraction limits, or methods for determining these limits from time to time, providing water for the environment, setting rules for the trade in water access entitlements and water allocations and setting principles and conditions for the sustainable take and use of water. Water allocation plans aim to balance social, economic and environmental needs for water and improve water security for all users. Community consultation must take place before a water resource is prescribed and during the development of a water allocation plan.

Prescription provides a cap on water take which establishes the scarcity that helps give rise to a water market.

Water allocation plans are reviewed every five years after adoption by the Minister. Required changes to a water allocation plan are identified in the review and if necessary an amended plan will be developed.

\subsection{River Murray}

The Water Allocation Plan for the River Murray Prescribed Watercourse was adopted in 2002. In 2009 the Plan was amended to facilitate unbundling of water rights, but without amending the existing policies within the Plan [7]. 


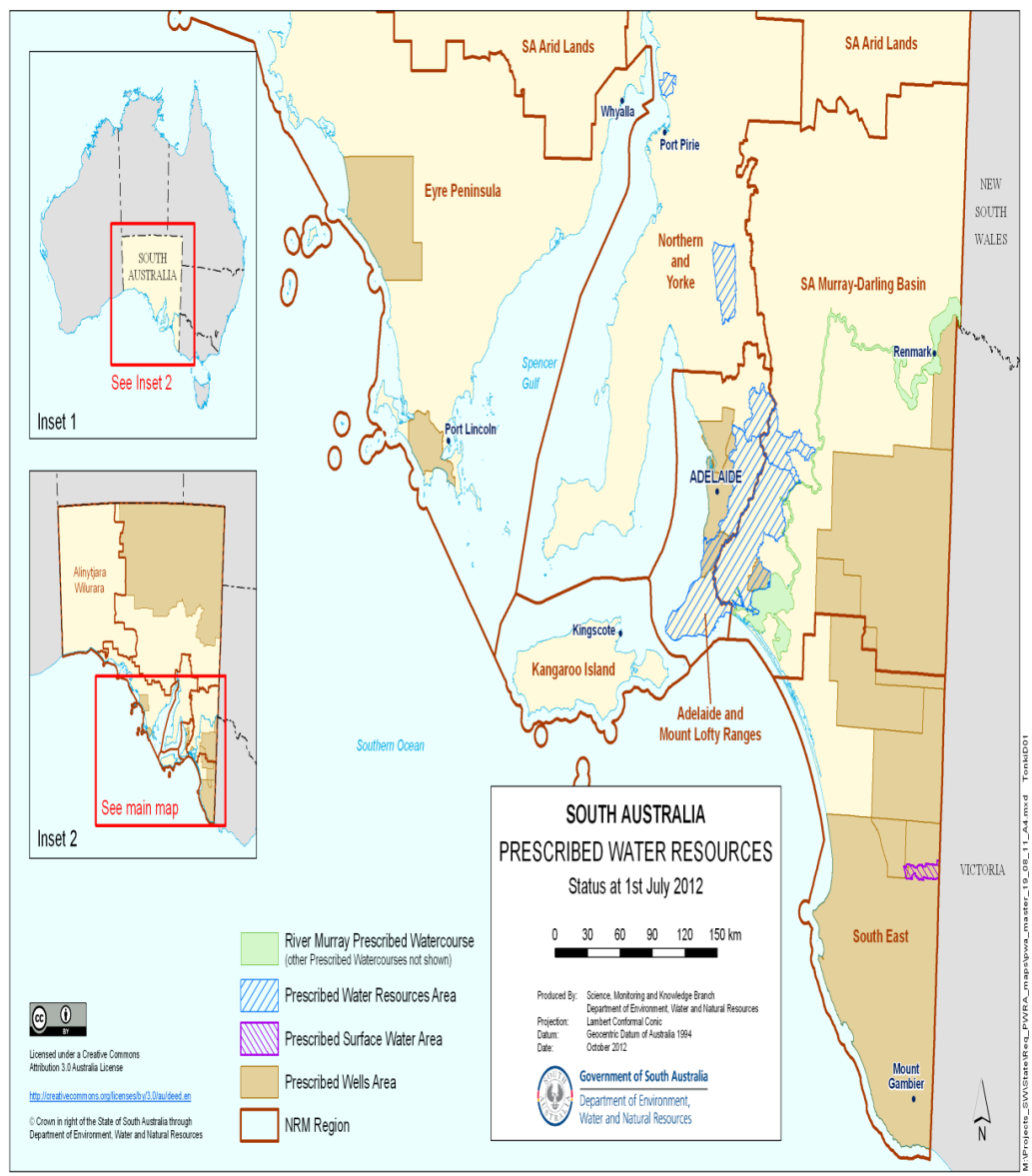

Figure 1: $\quad$ South Australian prescribed water resources.

The River Murray is a regulated river with major upstream storages (Hume (3,005 GL) and Dartmouth, (3,856 GL). There are 14 weirs on the river below the Hume Dam wall to the barrages which separate Lake Alexandrina from the Coorong and the mouth of the River Murray. The River Murray has a channel distance of $2530 \mathrm{~km}$, of which 683km is in South Australia [8].

The South Australian section of the river supports permanent plantings (grapes, citrus, and almonds), annual plantings (vegetables), dairy, a number of towns and population centres, and major off takes for Metropolitan Adelaide. There are in excess of 3,800 entitlement holders with the equivalent of $855 \mathrm{GL}$ on licence in the South Australian River Murray (plus many times that available through the interstate allocation market).

The South Australian River Murray experienced unprecedented volumes and numbers of allocation and entitlement trade during the Millennium drought. 
South Australia was a net importer of allocation water every year between 200708 and 2010-11. Net volumes of allocation traded into South Australian ranged between 69 GL to 336 GL during these years. Volumes of entitlement trade in South Australia ranged between nine and 28 GL per year over the same period [9].

In the 2011-12 year the trade in entitlements increased significantly due to the Commonwealth government's targeted Restoring the Balance buyback program aimed at increasing Commonwealth holdings of water entitlements to be used to specifically improve environmental outcomes [10].

\subsection{Other South Australian regions}

The volume and number of trades in other prescribed water resource areas have been much less than those for the River Murray [9]. Most of the other prescribed water resources in South Australia have less than 500 entitlement holders. The exceptions are the Lower Limestone Coast area in the South East of the state (approximately 3,400) and the Northern Adelaide Plains area (approximately $1,200)$. The volumes of most of these water resource areas are also small in comparison to South Australia's River Murray. The Lower Limestone Coast has a greater volume listed than the River Murray, but no other prescribed water resource has more than $200 \mathrm{GL}$ in its consumptive pool, and most have less than 10 GLs [12].

These lower levels of trade have been attributed to factors such as water rights remaining bundled, different nature of the water resources (mainly groundwater systems), with a different irrigation use profile and a lack of interstate trade options. Most of the resources have a smaller total volume and a small number of licence holders that can trade.

The different nature of South Australia's water resources, different levels of market development, activity and drivers, and the statutory nature of the state water planning process led to the decision that a state policy was needed to establish an ordered, transparent assessment of how, and to what extent, unbundling would suit each of the prescribed water resources of the state.

\section{Policy development}

The starting point for the development of the Policy Statement for the Implementation of Unbundling Water Rights in South Australia (the Policy Statement) [6] was a number of questions and discussions concerning the application of unbundling of water rights to water resources that were dominated by unregulated ephemeral watercourses, farm dams capturing surface water and fractured rock aquifers.

A number of workshops followed with scientists, policy, legal and regional planning staff to explore the issues and considerations required to unbundle different water resources.

The result of the workshops was general agreement that the unbundled water rights instruments could be applied across a large variety of water resources, but 
that depending on the nature of the water resource and the maturity of the water market, the introduction of unbundling could result in significantly increased complexity without generating the benefits in terms of clarity around water rights and facilitation of water trade. For example the management of surface water take by farm dams is based on a cap on dam capacity in a catchment, but there are also limits on the volume that can be diverted and the volume that can be taken from a dam. Therefore fully unbundling water rights would create three separate but linked water markets: dam capacity rights, diversion rights and extraction rights. This level of complexity is not easily justified, given the limited extent of the water market for such water resources and would in fact not create more clarity around water rights.

A series of questions were developed to undertake a feasibility and benefit assessment to determine the extent of unbundling of water rights and discussions were held on the timing of undertaking such an assessment in relation to the five year review cycle of water allocation plans and the transitional arrangements under the current NRM Act [1], which allow continuation of expressing water rights in a bundled manner as an interim arrangement.

The feasibility and benefit assessment policy was trialled with DEWNR policy and scientific staff and regional staff from the Eyre Peninsula. The trial process was completed in a day and the outcome was considered realistic, defendable and sensible. It also highlighted that the feasibility and benefit assessment needs to be undertaken as part of the water allocation planning process, because the outcome is highly dependent on the management objectives and therefore the proposed management arrangements for each prescribed water resource.

The revised draft Policy Statement was formally distributed to the Presiding members of the NRM Boards for feedback. This resulted in further minor refinements. The finalised policy statement was approved by DEWNR and the Minister in early August 2012.

\section{Policy statement for the implementation of unbundling water rights in South Australia}

The Policy Statement [6] reaffirms South Australia's commitment to unbundling water rights, but introduces flexibility around the extent of unbundling in each water resource. It recognises that expressing water access entitlements as an ongoing right to a share of available water will be beneficial for all water resources as it provides greater clarity around the reliability of water allocations and provides a more transparent mechanism to deal with short and long-term variability in a water resource.

However the separation of conditions for taking and/ or using water from the water access entitlement and/or water allocation may not always be the best option. Whether separate water resource works approvals and/or site use approvals are issued or whether conditions for taking and/or using water remain attached to the water access entitlement and/or water allocation will depend on the outcomes of the joint DEWNR and NRM Board feasibility and benefits 
assessment. The feasibility and benefit assessment covers the physical resource, the level of local knowledge and understanding of water rights and water markets, the potential of trade, complexity of the specific resource, governance and administrative issues and considers water resource management issues and their interaction with the potential unbundling.

The following questions have been developed to guide the feasibility and benefit assessment [6]:

- Are there gaps in knowledge about the water resource that impact on determining consumptive pool boundaries?

- What are the required water resource management arrangements and are they better supported by unbundling water rights?

- Does unbundling streamline or complicate water resource management, water rights administration and processes for water users?

- Does unbundling facilitate water markets and water trade; this may depend on the complexity of water resource management issues, but it can also depend on the maturity of the market and the level of understanding and confidence of the licensees. In addition, any assessment should consider any advantages from expediting trade.

- To what extent are other prescribed water resources within the same region unbundled?

- To what extent are inter-catchment or inter-basin water transfers occurring and what is the impact of potential different management arrangements between these catchments?

- Are there other outstanding issues that may need to be resolved prior to the introduction of unbundled water rights, for example, conversion to volumetric allocations, addressing over-allocation, dealing with unlicensed water use, such as stock and domestic water use or interception and use by forestry?

- Are there intergovernmental issues that need to be considered and the benefits of consistency with interstate arrangements?

- What are the current administrative practices and how will they have to change under an unbundled water rights system? Are there barriers in terms of costs, skills, IT systems, etc?

Each question requires a varying degree of detail and analysis as not all issues arise to the same degree in each water allocation plan. In most cases a fullydocumented feasibility analysis that identifies strengths, weaknesses, opportunities and threats of unbundling each prescribed water resource based on current knowledge will be sufficient and can be the result of an expert panel workshop.

Where full unbundling of water rights does not occur, the conditions of take and/or use of water remain attached to the water licence and/or the water allocation. This is known as partial unbundling. This will need to be supported by an exemption regulation under the NRM Act, to remove the need to issue separate site use and/or water resource works approvals for a specific water resource. It has been recognised that in the long-term, amendments to the NRM 
Act itself would be preferable to more explicitly support the flexibility in the implementation of unbundling water rights [11].

Regardless of whether water rights are fully or partially unbundled, the benefits include:

- a clear distinction between an ongoing right to access water (water access entitlement) and the actual volume received (water allocation);

- $\quad$ quicker and more efficient transfer of water access entitlements and water allocations, without the need for technical and site assessments;

- clarification of water rights for banks and financial institutions that may provide mortgages against those rights;

- a transparent way to deal with seasonal or long-term variations in the water resource's condition;

- clarification of the ownership attributes of the water as separate from the commitments and obligations associated with its taking and use.

Where water rights are fully unbundled, additional benefits include:

- no need to apply to vary conditions on a water licence or water allocation following a transfer;

- $\quad$ allowing for tailored policies to be developed for managing the impacts of taking and using water;

- greater flexibility in the options for managing water including dealing with variability in a water resource.

\subsection{Implications for water trade}

Transfers relate to changes in ownership or control of water access entitlements and water allocations. A 'transfer' is also referred to as a 'trade' in the water market. Transfer of water access entitlements and water allocations are easier in an unbundled water rights system. Changes in ownership do not impact on water resource management - separate approvals manage the take and use water (in the case of a fully unbundled arrangement), or a variation to the conditions on the water access entitlement or water allocation can be sought subsequent to the transfer (in case of partial unbundling).

In a fully unbundled situation, if someone holds a water licence with water access entitlements and/or a water allocation, but has no approvals to take and/or use the water, that person is not authorised to take or use the water. The person still holds an asset that can be transferred.

In a partial unbundled situation, where conditions for taking and/or using water are still linked to the water access entitlement and/or water allocation, the transfer of water rights will still remain a straight transfer of ownership, but the subsequent owner will have to apply to have any conditions for take and use varied, following the transfer of ownership.

\subsubsection{River Murray}

The NWC [9, 10] have demonstrated how successful trade along the River Murray has been since 2007. The Rural Industries Research and Development 
Corporation [13] highlighted the great difficulty in attributing trading success to specifically drought or commodity prices.

Unbundled water rights supported faster and easier processing of allocation trade. This assisted irrigators of the SA River Murray to survive the Millennium drought. Although many irrigators were severely financially stretched and farmed at much reduced levels, the majority were able to survive the drought with much of their permanent plantings intact and a much greater understanding of how and when to trade and awareness of the flexibility that trade offered to their businesses. This flexibility has manifested itself in many ways: expanding planted areas using allocation water, selling any unused volume of allocation for cash flow, decisions on financial viability to grow stock feed or to purchase stock feed, and using the price of water as a significant factor in farm planning. The speed at which allocations can now be traded is not instantaneous, but the COAG service standards are generally met [14]. Development of the National Water Market System linking the different registers across the Murray-Darling Basin is under development and this major undertaking should allow a significant step forward in transfers, smart forms automatically tailored to reflect the requirements of the jurisdictions processing the trades, and an even quicker finalisation of a valid application.

\subsubsection{Other water resources}

The process of unbundling water rights is gradually being applied to other water resources in South Australia, as part of the development of the next water allocation plans for those resources. The prescribed groundwater resources on the Eyre Peninsula already had a variable water allocation that recognised the dependency on rainfall and recharge, so the unbundled water rights concepts are more readily applied in this situation. There appear to be no obvious impediments to fully unbundling water rights for these water resources. There are some challenges in applying unbundled water rights to the Adelaide Plains in terms of accounting for the drainage and subsequent extraction of stormwater into aquifers and management of the use of recycled water. The issue of water rights to plantation forestry, proposed in the prescribed groundwater in the South East of South Australia, will also create a challenge to unbundling of water rights.

The assessment of the feasibility and benefits of unbundling water rights to water resources with extensive surface water take by farm dams and/ or fractured rock aquifers is still to commence. In all cases, the volumes of water trade will be significantly smaller than those for the River Murray in South Australia, but other benefits from unbundling water rights in terms of clarity in water rights and opportunities to improve water resource management will be the main drivers for reform of water rights for these resources.

\section{Conclusions}

The Policy Statement for the Implementation of Unbundling Water Rights in South Australia provides a flexible and adaptive approach to water rights reform 
and ensures that unbundling of water rights occurs in a manner that is feasible and beneficial for each water resource. The Policy Statement is a logical response to the variability in the nature of the water resources, the understanding of the water resources, the resource management issues, the potential and current extent of the water market and the level of understanding and confidence in operating in the water market

\section{References}

[1] Natural Resources Management Act (2004) http://www.legislation.sa. gov.au/LZ/C/A/NATURAL\%20RESOURCES\%20MANAGEMENT\%20A CT\%202004.aspx

[2] National Water Commission, Australian Water markets Report 2010-11, Canberra, 2011.

[3] The Council of Australian Governments' Water Reform Framework, Extracts from Council of Australian Governments: Hobart, 25 February 1994 Communiqué, Environment Australia, 1994, http://www.environment.gov.au/water/publications/action/policyframework .html

[4] National Water Initiative http://www.nwc.gov.au/home/watergovernancearrangements-in-australia/national-arrangements/ Intergovernmental-agreement-on-a-National-Water-Initiative

[5] National Water Commission, Water Markets in Australia, A Short History, Canberra, 2011.

[6] DEWNR, SA Policy Statement Policy on the Implementation of Unbundling Water Rights in South Australia, Policy statement http://www.waterconnect.sa.gov.au/WaterManagement/WaterPlanning/Doc uments/policy\%20statement.pdf

[7] Water Allocation Plan for the River Murray Prescribed Watercourse http://www.samdbnrm.sa.gov.au/Portals/9/PDF's/Water/River\%20Murray\% 20Water\%20Alloc\%20plan.pdf

[8] http://www.ga.gov.au/education/geoscience-basics/landforms/longestrivers.html

[9] National Water Commission, Australian water markets: trends and Drivers 2007-08 to 2010-11, Canberra, 2011.

[10] National Water Commission, The impacts of water trading in the southern Murray-Darling Basin An economic, social and environmental assessment Canberra, 2010.

[11] DEWNR, Unbundling Water Rights General Information http://www.waterconnect.sa.gov.au/WaterManagement/WaterPlanning/Doc uments/Unbundling\%20FAQs.pdf

[12] pers com DEWNR customer service staff, Adelaide, May 2012.

[13] Rural Industries Research and Development Corporation, National water Commission and Murray-Darling basin Commission, The economics and Social Impacts of water trading, Case studies in the Victorian Murray Mallee Frontier Economics in association with Tim Cummins and 
associates, Dr Alistair Watson, and Dr Elaine Barclay, and Dr Ian Reese of the Institute for Rural Futures, University of New England, By, September 2007.

[14] National Water Commission, The impacts of water trading in the southern Murray-Darling Basin between 2006-07 and 2010-11, Canberra, 2012. 